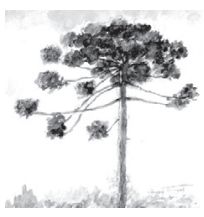

\title{
Polymorphic DNA fingerprinting patterns in distinct Chromobacterium violaceum strains using ERIC-PCR analysis
}

\author{
Padrão polimórfico de amplificação de elementos repetitivos \\ em distintas cepas de Chromobacterium violaceum por \\ análises de ERIC-PCR
}

\author{
Jane Eyre Gabriel ${ }^{[a]}$, Érica da Silva Lopes ${ }^{[\mathrm{b}]}$, Eloise Pavão Guerra Slompo ${ }^{[\mathrm{c}]}$, \\ Humberto Maciel França Madeira ${ }^{[\mathrm{d}]}$, Kárita Cláudia Freitas Lidani ${ }^{[\mathrm{e}]}$
}

\footnotetext{
[a] Ph.D. in Science (Nuclear Energy in Agriculture), Universidade de São Paulo (USP), associate professor I at the Universidade Federal do Vale do São Francisco (UNIVASF), Petrolina, PE - Brasil, e-mail: eyre.gabriel@gmail.com

[b] Pharmacist, Pontifícia Universidade Católica do Paraná (PUCPR), Curitiba, PR - Brasil.

[c] Biologist, Pontifícia Universidade Católica do Paraná (PUCPR), Curitiba, PR - Brasil.

[d] Ph.D. in Animal Science, University of Nebraska, professor at the Pontifícia Universidade Católica do Paraná (PUCPR), São José dos Pinhais, PR - Brasil, e-mail: h.madeira@pucpr.br

[e] Biomedical microbiologist, Universidade Católica do Paraná (PUCPR), Curitiba, PR - Brasil, e-mail: kari.lidani@gmail.com
}

\begin{abstract}
In the present study, distinct Chromobacterium violaceum strains were genetically characterized from polymorphic DNA fingerprinting patterns. Such assays were performed in presence of primer ERICII, originally designed from enterobacterial intergenic repetitive element sequences. Clustering analysis of the ERIC-PCR products and genetic similarity phenogram were estimated by using the coefficient of Sorensen-Dice and the UPGMA algorithm in the NTSYS-pc computer program. Genotypic diversity and the Shannon gene diversity indexes among the bacterial strains were calculated using the population genetics package POPGENE. Four main groups including individuals belonged to specific strains were defined by clustering analysis of ERIC-PCR products, in which similarity coefficients varied from 0.57 to 1 The inter-strain genetic distance and identity calculations revealed that the largest distance was observed between C. violaceum ATCC12472 and 07.1 strains (0.6414) and that the greatest identity between those identified as C. violaceum ATCC12472 and CBM strains (0.7622), confirming the pattern generated in the similarity phenogram. Considering the accentuated reproducibility in amplification
\end{abstract}


reactions and the highly polymorphic DNA fingerprinting profile observed for each bacterial strain, these findings create real possibilities for the detection of C. violaceum strains in microbial mixed cultures through ERIC-PCR assays.

Keywords: Chromobacterium violaceum. ERIC-PCR. Microbial biodiversity. Polymorphic DNA fingerprintings.

\section{Resumo}

No presente estudo, cepas de Chromobacterium violaceum foram geneticamente caracterizadas por ensaios de amplificação na presença do primer ERICII, originalmente construído a partir de sequências de elementos repetitivos, presentes em regiões intergênicas de enterobactérias. Os graus de similaridade e o fenograma de agrupamento foram estabelecidos por meio do coeficiente de Sorensen-Dice (SD) do algoritmo UPGMA, programa NTSYS-pc, enquanto os valores de diversidade e identidade genética entre as cepas testadas foram determinados por análises ao programa POPGENE. O número de fragmentos amplificados variou de 15 (cepa 27.1) a 17 (cepas CBMA-1 e ATCC12472), com tamanhos compreendidos entre 150 a 3.000 pb. Exceto por um único exemplar da cepa 07.1, todos os demais indivíduos apresentaram um perfil de amplificação do DNA e característico para cada cepa testada. As análises de caracterização molecular revelaram maior distância genética entre as cepas ATCC12472 e $07.1(0,6414)$ e maior identidade genética entre as cepas ATCC12472 e CBM $(0,7622)$, confirmando o padrão gerado no fenograma de similaridade. Tendo em vista a acentuada reprodutibilidade das reações de amplificação e o padrão de amplificação altamente polimórfico observado para cada cepa bacteriana, as descobertas apresentadas no presente estudo criam reais possibilidades para a detecção de cepas de C. violaceum em culturas microbianas por análises de ERIC-PCR. Além disso, tais descobertas ainda fornecem novas evidências da alta biodiversidade observada entre cepas pertencentes a essa espécie.

Palavras-chave: Chromobacterium violaceum. ERIC-PCR. Biodiversidade microbiana. Polimorfismo de DNA.

\section{Introduction}

The Chromobacterium violaceum is a free-living bacterium commonly found in the soil and in the water from tropical and subtropical regions around the world. The violacein represents the major pigment produced for this microorganism and several studies have intensively investigated its activity as bactericide, tumoricide and anti-viral agent $(1,2)$. Recently, the complete genome sequence of C. violaceum had provided relevant clues about its physiological adaptation to tropical soils and aquatic habitats, its capacities as an opportunistic pathogen, and its potential biotechnological and pharmaceutical applications (3). Nevertheless, few reports in literature have evaluated the degree of biodiversity among distinct strains of C. violaceum; although this bacterium represents an important ecosystem component of Amazon region.

Under the past decade, arbitrary amplification of polymorphic DNA sequences, such as random amplified polymorphic DNA (RAPD), has extensively been reported as a method for the genetic characterization of microorganisms (4). As an alternative to this arbitrary approach, known consensual regions can be amplified with single DNA primers in a way which gives rise to polymorphic DNA fingerprints. The 124 to 127 bp enterobacterial repetitive intergenic consensus (ERIC) elements, otherwise known as intergenic repeat units, have also been discovered in the genomes of the aforementioned organisms as well as other gram negative species and are present at approximately 30 to 150 copies $(5,6)$. The function of these highly repeated and conserved elements is not yet well elucidated, nevertheless, several evidences have suggested their involvement in stabilizing $\mathrm{mRNA}$, in translational coupling between genes, in homologous recombination, in chromosomal explain its DNA sequence conservation and ubiquitous distribution. Higgins et al. (7) gave evidences that these repeated elements represent "selfish" DNA sequences, which are maintained and propagated via gene conversion. Therefore, amplification-based DNA fingerprinting techniques have been used as a powerful tool in the molecular genetic analysis of the genetic biodiversity in a great variety of prokaryotic organisms $(4,8)$. 
Within this context, the aim of the present study was to characterize genetically distinct $C$. violaceum strains from their polymorphic DNA fingerprinting patterns by using ERIC-PCR analysis.

\section{Materials and methods}

\section{Strains and growth conditions}

Four C. violaceum strains designed originally as ATCC12472, CBMA-1, 07.1 and 27.1 were investigated in the present study. The C. violaceum strain ATCC12472 was obtained from the Fundação Tropical de Pesquisas André Tosello, Campinas (São Paulo, Brazil), whereas the strains CBMA-1,07.1 and 27.1 were assigned from the Embrapa Soja, Londrina (Paraná, Brazil). These strains were plated into nutrient agar containing $250 \mu \mathrm{g} / \mathrm{mL}$ of ampicilin for 16 hour incubation at $30^{\circ} \mathrm{C}$.

\section{Genomic DNA extraction and ERIC-PCR assays}

Saturated cultures from colonies isolated of each C. violaceum strain, have grown aerobically in 6 $\mathrm{mL}$ of nutrient broth (NB) containing $250 \mu \mathrm{g} / \mathrm{mL}$ of ampicilin for 16 hour incubation at $30^{\circ} \mathrm{C}$, and were sampled for extraction of the total genomic DNA, as described by Sambrook and Russell (9). Pellet of cells was lysated in buffer containing 50 $\mathrm{mM}$ glucose, $25 \mathrm{mM}$ Tris- $\mathrm{HCl}, \mathrm{pH} 7.5,10 \mathrm{mM}$ EDTA, pH 8.0 and 1\% SDS. After incubation for 1 hour at $55{ }^{\circ} \mathrm{C}$, samples were submitted to extraction with phenol:chloroform (1:1) and centrifuged at $12,000 \mathrm{xg}$ for 20 minutes. Approximately $800 \mu \mathrm{L}$ of aqueous phases was precipitated with two volumes of absolute ethanol by incubating for 1 hour at room temperature. Genomic DNA pellet was resuspended in TE buffer $(10 \mathrm{mM}$ Tris- $\mathrm{HCl}, \mathrm{pH}$ 7.5, $1 \mathrm{mM}$ EDTA, pH 8.0) containing $50 \mu \mathrm{g} / \mathrm{mL}$ of RNase (Promega) and incubated at $37^{\circ} \mathrm{C}$ for 1 hour for cleavage of contaminating RNA molecules. The concentration of genomic DNA samples was estimated in spectrophotometer (Beckman, model DU530) and the integrity of these samples was visualized on agarose gels.

The primer ERICII 5'AAGTAAGTGA CTGGGGTGAGCG3' used in the amplification reactions, was originally designed from the central inverted repeat of the ERIC consensus sequence located in extragenic regions of various enterobacteria $(5,6)$. Under specific experimental conditions, the PCRs were performed from $250 \mathrm{ng}$ of genomic DNA template, $0.5 \mu \mathrm{M}$ primer ERICII, $2.5 \mathrm{mM}$ $\mathrm{MgCl}_{2}, 0.4 \mathrm{mM}$ dNTPs and $0.2 \mathrm{u}$ Taq DNA polymerase (Invitrogen) in PCR buffer 1x concentrated $(50 \mathrm{mM} \mathrm{KCl}, 20 \mathrm{mM}$ Tris-HCl, $\mathrm{pH} 8.4$ ), in a final volume at $25 \mu \mathrm{L}$. After denaturation for $30 \mathrm{sec}$ at 95 ${ }^{\circ} \mathrm{C}$, the samples were submitted to annealing for 1 $\min$ at $50{ }^{\circ} \mathrm{C}$ and extension for $5 \mathrm{~min}$ at $72{ }^{\circ} \mathrm{C}$, in a total of 40 cycles. The ERIC-PCR products were separated on a $1.5 \%$ agarose gels prepared with $\mathrm{TBE}$ 1x (90 mM Tris-HCl, pH 7.5, 1 mM EDTA, pH 8.0, $100 \mathrm{mM}$ boric acid), stained with ethidium bromide and photographed by using digital camera (Kodak ${ }^{\mathrm{TM}}$, model EDAS 290). All assays described above were carried out in triplicate in order to confirm the reproducibility of results generated.

\section{Data analysis of ERIC-PCR products}

Clustering analysis of the ERIC-PCR products and genetic similarity phenograms among the strains were established by using the coefficient of Sorensen-Dice (SD) and the UPGMA (unweighted pair-group method, with arithmetic mean) algorithm in the NTSYS-pc version 2.0 (10) computer program. Genotypic diversity and the Shannon gene diversity indexes among the bacterial strains were calculated using the population genetics package POPGENE 1.31 (11).

\section{Results and discussion}

In the present study, we characterized genetically distinct $C$. violaceum strains based on their polymorphic DNA fingerprinting patterns. The size and the number of amplified bands were established for each strain by visualizing of the ERIC-PCR products on agarose gels, as observed in Figure 1. The eletrophoretical profile generated from ERIC-PCR products in the ATCC12472 and CBMA.1 strains yielded multiple distinct DNA fragments of sizes ranging from 100 to 3,000 bp and the number of amplified bands was corresponding to 17 bands per individual. Alternatively, the C. violaceum 27.1 and 07.1 strains also presented a 
typical DNA amplification pattern in comparison to other strains analyzed (Figure 1). In these strains, it was observed that the size of ERIC-PCR products ranged of 150 to $3,000 \mathrm{bp}$, whereas the number of amplified bands was corresponding to 15 and 16 for 27.1 and 07.1 strains, respectively.

Although some bands in common (PCR products of analogous mobility) are identified between intra and inter-individual strains, the ERICPCR analysis revealed clearly distinct DNA amplification profiles from all strains analyzed, as shown in Figure 1. The most common disadvantage pointed into arbitrary amplification protocols concerning the reproducibility during performance of assays $(4,12)$. Therefore, results presented in this study provide strong evidences of the accurate repeatability in eletrophoretical patterns generated from amplification reactions (Figure 1), suggesting that the polymorphic DNA fingerprinting method used in the present study is extremely sensible to detect minor differences between different strains at the same bacterial strains, the same result documented for Escherichia colistrains (13). These findings reinforce the use of ERIC-PCR technique as a powerful tool in the molecular genetic analysis by discriminating individual isolates and identifying of the bacterial strains and for bacterial taxonomy, as well as it may reveal relevant phylogenetical relationships.

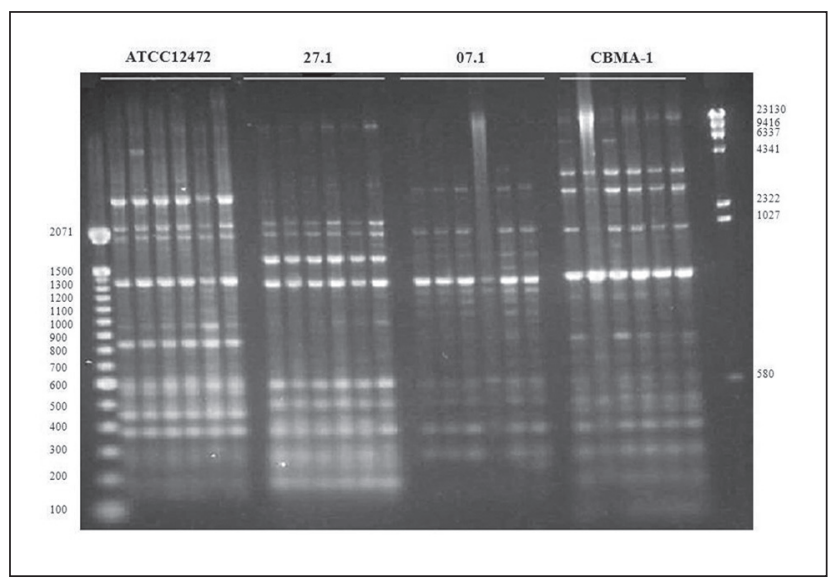

Figure 1 - PCR profiles for four Chromobacterium violaceum strains using primer ERICII. Strains tested: lanes 1 to 6 - ATCC12472; lanes 7 to 12 - 27.1; lanes 13 to 18 - 07.1 and lanes 19 to 24 CBMA-1. Molecular DNA Ladders: $\lambda$ DNA/ HindIII fragments from Invitrogen Inc and DNA molecular marker II from GE Healthcare
Repetitive element sequences, usually situated in the intergenic space of prokaryotic genomes, as the ERIC sequences, are often highly conserved among dissimilar bacteria, and they have successfully been used to evaluate the bacterial diversity $(8,14)$. Based on sharpness of amplified DNA bands, four main groups including individuals belonged to specific strains were defined by clustering analysis of ERICPCR products, in which similarity coefficients varied from 0.57 to 1 (Figure 2 and Table 1). Except by one unique exemplar belonged to strain 07.1, our results showed typical polymorphic amplification patterns for each strain tested (Figure 2). As shown in Table I, the inter-strain genetic distance and identity calculations based on Nei (15) revealed that the largest distance was observed between C. violaceum ATCC12472 and 07.1 strains (0.6414) and that the greatest identity between those identified as C. violaceum ATCC12472 and CBM strains (0.7622), confirming the pattern generated in the similarity phenogram (Figure 2). Under our analysis, the genetic diversity estimated from the percentage of polymorphic loci at the C. violaceum ATCC12472 and 27.1 strains was $16 \%$, whereas the 07.1 and CBMA-1 strains presented values corresponding to $36 \%$ and $12 \%$, respectively. Based on genic variation statistics for all loci, the data concerning the number and the percentage of polymorphic loci for four strains was 20 and $80 \%$, respectively.

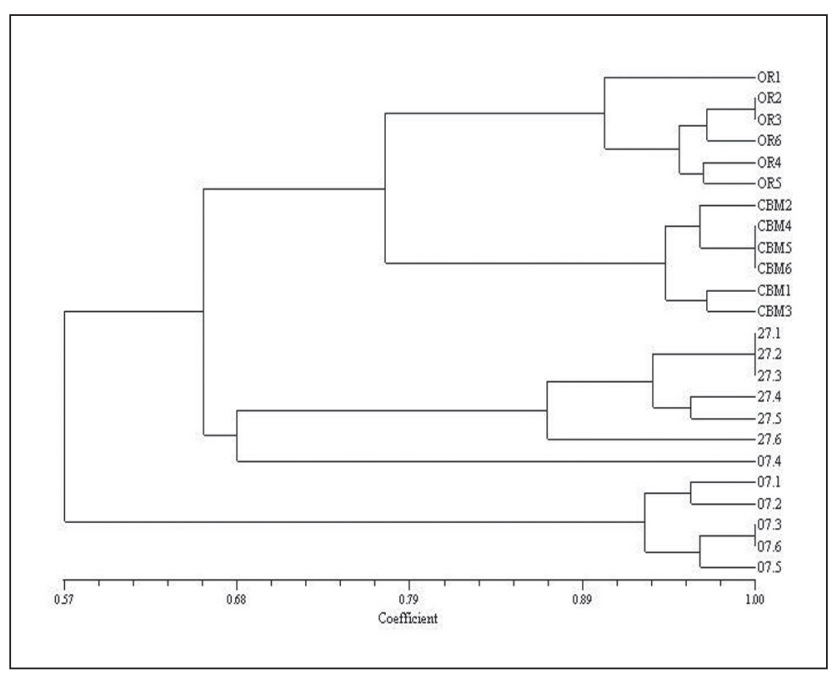

Figure 2 - Genetic similarity phenogram generated with the Sorensen-Dice coefficient and UPMGA algorithm for distinct Chromobacterium violaceum strains ATCC12472 (OR), CBMA-1, 07.1 and 27.1 
The C. violaceum strains have been extensively characterized concerning their microbiological properties $(1,2)$, although few reports in literature have described the polymorphism DNA pattern in these strains. In a recent study, Hungria et al. (17) showed a high level of genetic diversity in isolates of C. violaceum from the waters of river Negro in Brazil. Such findings showed that Brazilian isolates would fit into at least two new clusters besides $C$. violaceum species by $16 \mathrm{~S}$ and $23 \mathrm{~S}$ ribosomal DNA sequence analysis. Alternatively, the genotyping of $C$. violaceum isolates was established by rec $A$ PCR-RFLP analysis, generating in a rapid nucleotide sequencebased approach to specifically identify and classify this bacterium at level of genospecies (18).

Table 1 - Nei's (15) genetic distance (above diagonal) and genetic identity (below diagonal), with Lynch and Milligan correction (16), between distinct Chromobacterium violaceum strains

\begin{tabular}{lcccc}
\hline & ATCC12472 & $\mathbf{2 7 . 1}$ & $\mathbf{0 7 . 1}$ & CBMA-1 \\
\hline ATCC12472 & $* * * *$ & 0.7021 & 0.5266 & 0.7622 \\
27.1 & 0.3536 & $* * * *$ & 0.7534 & 0.6557 \\
07.1 & 0.6414 & 0.2831 & $* * * *$ & 0.6321 \\
CDMA-1 & 0.2715 & 0.4221 & 0.4588 & $* * * *$ \\
\hline
\end{tabular}

The results presented in this study revealed that ERIC-like sequences are present at a highly polymorphic amplification pattern in the genomes of gram-negative C. violaceum bacteria, supporting and extending the findings described by Versalovic et al. (13) and de Bruijn (8). In a preliminary study, ERIC-PCR has been used for genetic differentiation of Enterobacter cloacae isolates (19), being evaluated as highly discriminative method for such application. The development of more sensible methods to discriminate bacterial communities is a crescent needed in the area of microbial ecology and in this respect our findings create real possibilities for the detection of C. violaceum strains in microbial mixed cultures through ERIC-PCR procedure. On the other hand, these results also provide new insights into the better understanding of the high biodiversity found in these bacterial strains.

\section{Acknowledgements}

The authors are grateful to Ministério da Ciência e Tecnologia (MCT)/Conselho Nacional de Desenvolvimento Científico e Tecnológico (CNPq) for financial support.

\section{References}

1. Durán N, Antonio RV, Jaun M, Pilli RA. Biosynthesis of a trypanocide by Chromobacterium violaceum. Wld J Microbiol Biotech. 1994;10:686-90.

2. Durán N, Menck CFM. Chromobacterium violaceum: a review of pharmacological and industrial perspectives. Crit Rev Microbiol. 2001;27:201-22.

3. Vasconcelos ATR, AlmeidaDF,Hungria M, Guimarães CT, Antônio RV, Almeida FC, et al. The complete genome sequence of Chromobacterium violaceum reveals remarkable and exploitable bacterial adaptability. Proc Natl Acad Sci USA. 2005;100(20):11660-5.

4. Tyler KD, Wang G, Tyler SD, Johnson WM. Factors affecting reliability and reproducibility of amplification-based DNA fingerprinting of representative bacterial pathogens. J Clin Microbiol. 1997; 35(2):339-46.

5. Sharples GJ, Lloyd RG. A novel repeated DNA sequence located in the intergenic regions of bacterial chromosomes. Nucleic Acids Res. 1990;18(22):6503-8.

6. Hulton CSJ, Higgins CF, Sharp PM. ERIC sequences: a novel family of repetitive elements in the genome of Escherichia coli, Salmonella typhimurium and other Enterobacteria. Mol Microbiol. 1991;5(4):825-34.

7. Higgins CF, McLaren RS, Newbory SF. Repetitive extragenic palindromic sequences, mRNA stability and gene expression: evolution by gene conversion? A review. Gene. 1988;72(1-2):3-14.

8. de Bruijn FJ. Use of repetitive (repetitive extragenic palindrome and Enterobacterial repetitive intergenic consensus) sequences and the polymerase chain reaction to fingerprint the genomes of Rhizobium meliloti isolates and other soil bacteria. Appl Environ Microbiol. 1992;58(7):2180-7.

9. Sambrook J, Russell DW. Molecular cloning: a laboratory manual. Cold Spring Harbor: Cold Spring Harbor Laboratory Press; 2001. 
10. Rohlf FJ. NTSYS-PC: numerical taxonomy and multivariate analysis system, version 1.80. Steauket: Applied Biostatistics; 1993.

11. Yeh FC, Boyle T, Yeh Z, Xiyan JM. Version 1.31: Microsoft Windows-based freeware for population genetic analysis. University of Alberta and Center for International Forestry Research; 1999.

12. Stumpf AN, Roggenkamp A, Hoffmann H. Specificity of enterobacterial repetitive intergenic consensus and repetitive extragenic palindromic polymerase chain reaction for the detection of clonality within the Enterobacter cloacae complex. Diagn Microbiol Infect Dis. 2005;53(1):9-16.

13. Versalovic J, Koenth T, Lupski JR. Distribution of repetitive DNA sequences in eubacteria and application to fingerprinting of bacterial genomes. Nucleic Acids Res. 1991;19(24):6823-31.

14. Namvar A, Warriner K. Application of enterobacterial repetitive intergenic consensus polymerase chain reaction to trace the fate of genetic Escherichia coli within a high capacity pork slaughter line. Int J Food Microbiol. 2006;108(2):155-63.

15. Nei M. Estimation of average heterozygosity and genetic distance from a small number of individuals. Genetics. 1978;89(3):583-90.
16. Linch M,Milligan BG. Analysis of population structure with RAPD markers. MolecularEcology. 1994;3:91-9.

17. Hungria M, Astolfi-Filho S, Chueire LM, Nicolás MF, Santos EB, Bulbol MR, et al. Genetic characterization of Chromobacterium isolates from black water environments in the Brazilian Amazon. Lett Appl Microbiol. 2005;41(1):17-23.

18. Scholz HC, Witte A, Tomaso H, Dahouk SA, Neubauer H. Genotyping of Chromobacterium violaceum isolates by recA PCR-RFLP analysis. FEMS Microbiol Lett. 2005;244(2):347-52.

19. Fernández-Baca V,Ballesteros F, Hervás JA, Villalón P, Domínguez MA, Benedí VJ, et al. Molecular epidemiological typing of Enterobacter cloacae isolates from a neonatal intensive care unit: three-year prospective study. J Hosp Infect. 2001;49(3):173-82.

Received: 08/07/2009

Recebido: 07/08/2009

Approved: 10/14/2009

Aprovado: 14/10/2009 